\title{
ESTIMATION OF CARBON EMISSION IN THE EX-MEGA RICE PROJECT, INDONESIA BASED ON SAR SATELLITE IMAGES
}

\author{
NUTHAMMACHOT, N. ${ }^{1}$ - PHAIRUANG, W. $.^{1,2}-$ StRATOULIAS, D. ${ }^{3,4^{*}}$ \\ ${ }^{I}$ Faculty of Environmental Management, Prince of Songkla University \\ P. O. Box 50 Kor-Hong, Hatyai, Songkhla 90112, Thailand \\ (e-mail: narissara.n@psu.ac.th (N.N.); worradorn.p@psu.ac.th (W.P.)) \\ ${ }^{2}$ Air Pollution and Health Effect Research Center, Prince of Songkla University \\ Hatyai, Songkhla 90110, Thailand \\ ${ }^{3}$ Department for Management of Science and Technology Development, Ton Duc Thang \\ University, Ho Chi Minh City, Vietnam \\ ${ }^{4}$ Faculty of Applied Sciences, Ton Duc Thang University, Ho Chi Minh City, Vietnam \\ *Corresponding author \\ e-mail: dimitris.stratoulias@tdtu.edu.vn; \\ (Received $1^{\text {st }}$ Nov 2018; accepted $28^{\text {th }}$ Jan 2019)
}

\begin{abstract}
This paper aims to estimate the extent of the burned area in ex-Mega Rice Project (MRP) (Block A and Block E), Central Kalimantan and quantify the carbon emission as a result of peat fires in this area. A Synthetic Aperture Radar TerraSAR-X image was the main input in this study. Preprocessing included radiometric calibration, geometric reprojection and speckle filtering (Gamma MAP 7 $\times 7$ kernel size). Maximum Likelihood (ML) classification was used for classifying burned areas. The classification result was validated based on data from the Kalimantan Forests and Climate Partnership report (KFCP). The burned area in 2010 as estimated by the TerraSAR-X satellite image HH/HV polarization was $47.6113 \mathrm{~km}^{2}$ (4761.13 ha). Main pollutants (carbon dioxide $\left(\mathrm{CO}_{2}\right)$, carbon monoxide (CO), particulate matter (PM), black carbon (BC) and organic carbon (OC)) emissions were estimated based on an empirical equation. The average annual carbon releases into the atmosphere from this area were estimated to be $173,019.46$ ton $\mathrm{CO}_{2}, 11,388.62$ ton $\mathrm{CO}, 1,149.81$ ton $\mathrm{PM}_{10}, 996.50$ ton $\mathrm{PM}_{2.5}$ 569.43 ton OC and 72.27 ton BC. This study suggests that the methodology proposed based on Earth Observation data can be used to locate burned areas in tropical environment and quantify carbon emissions.
\end{abstract}

Keywords: burned area, emission factor, earth observation, forest fire, Ex-mega Rice Project, TerraSAR-X, dual polarization

\section{Introduction}

Peatlands are wetland ecosystems frequently encountered in Southeast Asia. They play a vital role in the biosphere's biogeochemical processes (Immirzi, 1992). At a global scale, they hold an important ecological function as they represent a major store of soil carbon, sink for carbon dioxide and source for atmospheric methane (Strack, 2011); at a local scale they host habitats for several rare and endangered species (Posa, 2011). Page et al. (2011) estimated the volume of tropical peat to be $1758 \mathrm{Gm}^{3}(\sim 18-$ $25 \%$ of global peat volume) with $1359 \mathrm{Gm}^{3}$ located in Southeast Asia (77\% of all tropical peat). During the last decades, the area of tropical peat swamps has been reduced and degraded due to deforestation, drainage, fires, clearing for agriculture and oil palm plantations and illegal timber harvest (Peace Report, 2018; Koh et al., 2009). From all these causes of environmental degradation, fires are a unique one that can be 
attributed partially to anthropogenic interference, however sometimes they can occur naturally; for instance, it has been demonstrated that fires have been observed during El Niño events as a direct consequence of the extensive drought incurred from the latter (e.g. in 1997, 2002, 2004, 2006 and 2009) (Ballhorn et al., 2009; Putra et al., 2008). Therefore, monitoring of tropical peatlands is crucially important for inventorying the magnitude of carbon stock and estimating the pollutants emitted to the atmosphere.

Deforestation has been a major cause of peatland disturbance; in 2005, 25\% of all deforestation in SE Asia was on peatlands according to Rieley et al. (2008). Within Southeast Asia, Indonesia is the country with the largest share of tropical peat carbon stock estimated at 57.4 Gt (Page et al., 2011). In 1996, the Indonesian government initiated the Mega Rice Project (MRP) in the southern parts of Central Kalimantan. The aim of this project was to convert one million hectares of peat swamp forest to rice paddies. Consequently, forest cover decreased from $64.8 \%$ in 1991 to $45.7 \%$ in 2000 , and clearance has continued since then. The MRP project led to frequently large fire occurrences during dry seasons. Approximately 4,740 km${ }^{2}$ in MRP have been damaged from severe fire episodes in 1997 and released $0.19-0.23 \mathrm{Gt}$ of carbon to the atmosphere. This huge amount of carbon suggests that severe peat fires occurred in the MRP area (Putra et al., 2008).

Chemical species have long been detected and quantified directly from specialized satellite instruments such as the GOME instrument onboard ERS-2, the MODIS instruments onboard TERRA and AQUA satellites and the SCIAMACHY instrument onboard ENVISAT. Streets et al. (2013) provide a review on emission estimates from satellite retrievals. Another indirect approach to estimate gas emissions is to spatially quantify the phenomenon generating the emissions and then estimate the latter based on empirical relationships or models. This indirect approach is of special interest in land cover applications since Earth Observation has advanced significantly in estimating the spatial extent of deforestation activities and subsequently the calculation of environmental parameters (e.g. Kim et al., 2015; Zeng et al., 2018; Broich et al., 2017; Krasovskii et al., 2018; Joshi et al., 2015; Fawzi et al., 2018; Nugroho et al., 2018; Grinand et al., 2013). For instance, Carlson et al. (2013) estimated high-resolution carbon flux estimates from Kalimantan oil palm plantations based on land cover classification from Landsat data (at spatial resolution of $30 \mathrm{~m}$ ). In the context of forest fires, an immediate consequence is forest loss and the associated outcome is the pollution emissions during the combustion (Page et al., 2002; Hooijer et al., 2010). Forest fires result to emission into the atmosphere of particulate matter $\left(\mathrm{PM}_{10}, \mathrm{PM}_{2.5}\right)$, particulate black carbon (BC), organic carbon (OC) and gaseous emissions (carbon monoxide $(\mathrm{CO})$, carbon dioxide $\left(\mathrm{CO}_{2}\right)$, nitrogen oxides, non-methane volatile organic compounds (NMVOC), methane $\left(\mathrm{CH}_{4}\right)$, nitrous oxide $\left(\mathrm{N}_{2} \mathrm{O}\right)$, sulfur dioxide $\left(\mathrm{SO}_{2}\right)$ and ammonia $\left(\mathrm{NH}_{3}\right)$ ) (Shrestha et al., 2013). $\mathrm{CH}_{4}$ and $\mathrm{N}_{2} \mathrm{O}$ emissions from tropical peatlands are low (Strack, 2008). On a global scale, fire impacts the net carbon balance of global terrestrial ecosystems; this impact has been quantitatively assessed by Li et al. (2014). Recent research from Junpen et al. (2018) suggested that emissions from biomass open burning can be estimated based on burned area products derived from satellite data. In a similar context, Hawbaker et al. (2016) mapped the extent of burned area in the Southern Rocky Mountains, USA, subsequently use the LANDFIRE Fuel Characteristic Classification System to assign biomass loads and finally estimate biomass consumption and greenhouse gas emissions based on the CONSUME model. Several other studies have quantified burned area based on satellite data (e.g. Junpen et al., 
2013; Permadi and Oanh; 2013). A critical aspect in such methodological approach is the spatial resolution of the satellite image which plays an important role in the accuracy of the burned area estimation and subsequently the estimation of pollutants emissions (Belenguer-Plomer et al., 2018; Yun and Pritchard, 2018). For a review of the strengths and limitations of remote sensing in estimating tropical forest biomass, the reader is directed to Mitchard (2015) and Saatchi (2015).

The aim of this paper is to assess the burned area based on fine spatial resolution Synthetic Aperture Radar (SAR) satellite images and field data, and consequently quantify the carbon emissions through empirical relationships that occurred from peat fires in blocks A and $\mathrm{E}$ of the MRP.

\section{Materials and methods}

\section{Study area}

Central Kalimantan, Indonesia is the second largest province of the island of Kalimantan and the third largest province of the country, covering $153,800 \mathrm{~km}^{2}$. The climate is tropical with a significant amount of rainfall; the drier season usually begins in May and lasts until October while the wetter season covers the period between November and April. The temperature fluctuates between $25-27{ }^{\circ} \mathrm{C}$ and the rainfall ranges from 2,776 to $3,393 \mathrm{~mm}$ per year with an average of 145 rainy days annually (Moore et al., 2011). The central area of Central Kalimantan is covered by tropical forests while the southern area is swampy with an extensive river network. Peat swamp forest areas in Indonesia are primarily located at low altitudes in the coastal and subcoastal lowlands of Papau (4.6 Mha), Sumatra (8.3 Mha) and Kalimantan (6.8 Mha) (Page et al., 1999); central Kalimantan contains one of the largest tropical peatland areas in the world. Figure 1 presents the study area which is part of the MRP.

\section{Satellite data}

A SAR image was used in this study as the main input. TerraSAR-X is a high spatial resolution X-band SAR active system operating at $9.65 \mathrm{GHz}$ centre frequency. The satellite was launched in 2007 and provides single, dual or full polarization data at a spatial resolution between $1 \mathrm{~m}$ and $16 \mathrm{~m}$ depending on the mode of acquisition. A TerraSAR-X Single Look Slant Range Complex (SSC) product in the DLR-defined COSAR binary format and the associated Multi Look Ground Range Detected (MGD) product in GeoTiff format were provided by ASTRIUM GEO-Information. The MGD product is a multi-look product with reduced speckle and approximately square ground resolution cells. The image was acquired in dual polarization $(\mathrm{HH} / \mathrm{HV})$ StripMap imaging mode on 05/04/2010 with a $6.6 \mathrm{~m}$ spatial resolution and 37.489 incidence angle. The image coordinates are oriented along the flight direction and the ground range. A simple polynomial projection was performed in range to an ellipsoid in order to achieve approximately quadratic pixels. The advantage of this product is the fact that no image rotation to a map coordinate system has been performed and interpolation artefacts are thus avoided.

\section{Satellite image processing}

The TerraSAR-X image was preprocessed by applying sequentially radiometric calibration, geometric reprojection and speckle filtering. An absolute radiometric 
calibration of Sigma Naught $(\sigma 0)$ was performed providing radar reflectivity per unit area at ground range. The simplified approach was followed where Noise Equivalent Beta Naught (NEBN) was ignored. The image was then reprojected onto the Geographic Lat/Lon (WGS 84) Coordinate Reference System (CRS) using the nearest neighbour resampling method. Finally the Gamma MAP filter with $7 \times 7$ kernel window was applied to reduce the speckle noise of the image as it has been shown to provide the best results in a tropical environment (Nuthammachot et al., 2017).

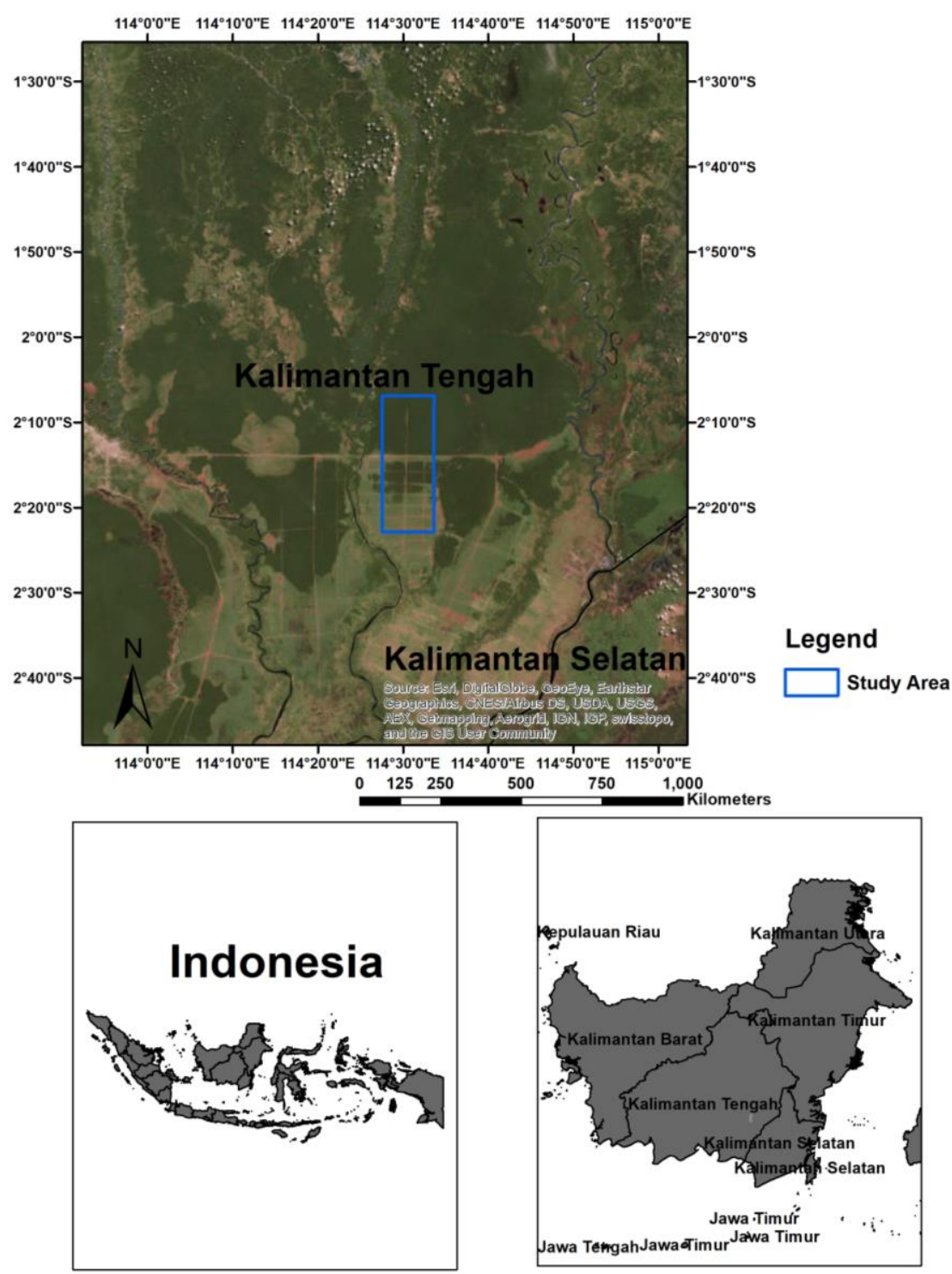

Figure 1. A true-colour satellite image representation of the study area in Central Kalimantan, Indonesia

For the detection of the burn areas the Maximum Likelihood (ML) algorithm was used to classify pixels corresponding to burned land as it is one of the most traditional classification algorithms developed, yet has been proven very powerful in a variety of remote sensing challenges. The thematic map produced indicating the burned area as estimated from TerraSAR-X dual polarization $(\mathrm{HH} / \mathrm{HV})$ was validated with the field 
data published in the Kalimantan Forests and Climate Partnership (KFCP) report (KFCP Vegetation Monitoring, 2014). The results of the validation were presented with an error matrix (contingency table) as suggested by Congalton (1991).

\section{Emission estimation}

The burned area calculated from the SAR data was used as an input to estimate the emission pollutants in this study area. Particulate matter and trace gas emissions from forest fires can be approximated based on the availability of field data in a given area. Hao and Liu (1994) present a methodology to estimate forest fire emissions (Eq. 1) based on which the emission of each pollutant can be quantified.

$$
\mathrm{Em}_{\mathrm{i}, \mathrm{j}}=\sum_{j} M_{j} \times \mathrm{EF}_{\mathrm{i}, \mathrm{j}} \times 10^{-3}
$$

where:

Emi, $\mathrm{j}=$ Emission of pollutant $\mathrm{i}$ from land cover type $\mathrm{j}$ (tonne/yr)

$\mathrm{Mj}=$ Amount of burned biomass on land cover type $\mathrm{j}$ (tonne/yr)

Efi, $\mathrm{j}=$ Emission factor of pollutant i from land cover type $\mathrm{j}(\mathrm{g} / \mathrm{kg}$ of dry matter)

The amount of biomass burned each year from forest fires was calculated by multiplying the factors burned area, fraction of total area burned annually, dry matter density and burning efficiency as presented in Equation 2. Dry matter density $\rho$ i and forest burned area fraction $\mathrm{fj}$ values were taken from the FAO Forest Resource Assessment (FAO, 2003).

$$
M_{j}=\mathrm{A}_{j} \times f_{j} \times \rho_{j} \times \eta_{j}
$$

where:

$\mathrm{Aj}=$ Area of land cover type $\mathrm{j}$ (ha)

$\mathrm{fj}=$ Fraction of total area burned annually of land cover type $\mathrm{j}$

$\rho j=$ Dry matter density (tonne/ha)

$\eta j=$ Burning efficiency (oxidized in the combustion)

The emission factors of forest burning in a tropical forest environment were adapted from Andreae and Merlet (2013) and are provided in Table 1. The unit of emission factors ( $\mathrm{g} / \mathrm{kg}$ dry mass residue burning) was calculated by the division of the mass concentration of a pollutant (e.g. $\left.\mathrm{CO}_{2}\right)\{\mathrm{g}\}$ and the dry mass residue before burning $\{\mathrm{kg}\}$. This parameter is reliable to use for pyrogenic emission factors for pollutants in tropical forest areas. In the literature, most of available $\mathrm{CO}_{2}$ emission factors from biomass burning especially from forest fires are reported higher than $1,000 \mathrm{~g} / \mathrm{kg}$, e.g. Andreae et al. (2001), Chaiyo and Garivait (2014), Shrestha et al. (2013). In case of a complete combustion, the carbon released into the atmosphere would be equal to the carbon in the form of $\mathrm{CO}_{2}$. As forest fire is frequently an incomplete combustion, the carbon discharged in the form of $\mathrm{CO}_{2}$ represents more than $90 \%$ of the total carbon lose; $\mathrm{CO}$ emissions account for less than $5 \%$ of the total carbon release and minor carbonaceous compositions comprise of BC and OC (Chaiyo and Garivait, 2014). Consequently, the emission factor for $\mathrm{CO}_{2}$ is higher comparing to other emission factors. 
Emission factors and other parameters i.e. dry matter density, burning efficiency for determining the biomass burned differ for each vegetation species, geographic location and environmental conditions. At global scale and national level, the estimation of emissions has been based on available guides such as the Intergovernmental Panel on Climate Change (IPCC) report 2006 for greenhouse gases emission inventory and research data or the approach proposed from Andreae and Merlet (2001). However, a country-specific value is needed to apply to Indonesia area for accurate data. In this study, we used primary data from Asian countries to estimate carbon emission. When the default parameters have been unavailable for Asia countries, the others parameters for a simlar climatic conditions and vegetation type have been the first choice (Junpen et al., 2013; Phairuang et al., 2017).

Table 1. Pyrogenic emission factors for pollutants of interest for the tropical forest environment (adapted from Andreae and Merlet, 2013)

\begin{tabular}{c|c|c}
\hline Pollutant (abbreviation) & Pollutant & Tropical forest $\mathbf{( g / \mathbf { k g } )}$ \\
\hline $\mathrm{CO}_{2}$ & Carbon dioxide & 1580 \\
$\mathrm{CO}$ & Carbon monoxide & 104 \\
$\mathrm{PM}_{10}$ & Particulate matter less than 10 microns in diameter & $6.5-10.5$ \\
$\mathrm{PM}_{2.5}$ & Particulate matter less than 2.5 microns in diameter & 9.1 \\
$\mathrm{OC}$ & Organic carbon & 5.2 \\
$\mathrm{BC}$ & Black carbon & 0.66 \\
\hline
\end{tabular}

\section{Results and discussion}

Burned areas enclosed in the MRP sites at Central Kalimantan, Indonesia were detected using a dual polarization TerraSAR-X image acquired in April 2010. Figure 2 depicts the burned area as reported by the KFCP report (KFCP Vegetation Monitoring, 2014) and as estimated from the SAR image classification followed in this paper. It is apparent that the spatial distribution of the binary classification results from the classification of the SAR image correspond closely to the results reported by the KFCP. We estimated that the cumulative burned area calculated from the SAR image processing algorithm accounts for $47.6113 \mathrm{~km}^{2}$ (4761.13 ha). The cumulative burned area reported from the reference map was $50.4128 \mathrm{~km}^{2}$ (5041.28 ha). It has to be noted that these two datasets refer to two consecutive years. Table 2 provides the accuracy assessment, with the reference data represented from the KFCP report (KFCP Vegetation Monitoring, 2014). The overall accuracy was $88.26 \%$. The commission error for the burned area was $26.21 \%$, which is attributed to the fact that several very small areas scattered around the image (salt and pepper effect) were classified as burned areas while they have been noise from the SAR image instead. A larger kernel in the speckle filter could have eliminated these pixels and reduce the commission error, however other artefacts would have been introduced in the image by selecting a kernel with a larger than $7 \times 7$ window size. The omission error was $33.80 \%$ and these are areas at the south-east side of the image and further away from the drainage canals; either the 
classifier has underestimated the burned effect in this part of the image, either this was a direct consequence of the difference in date acquisition of the two data sets.

\section{Burned Area Map}

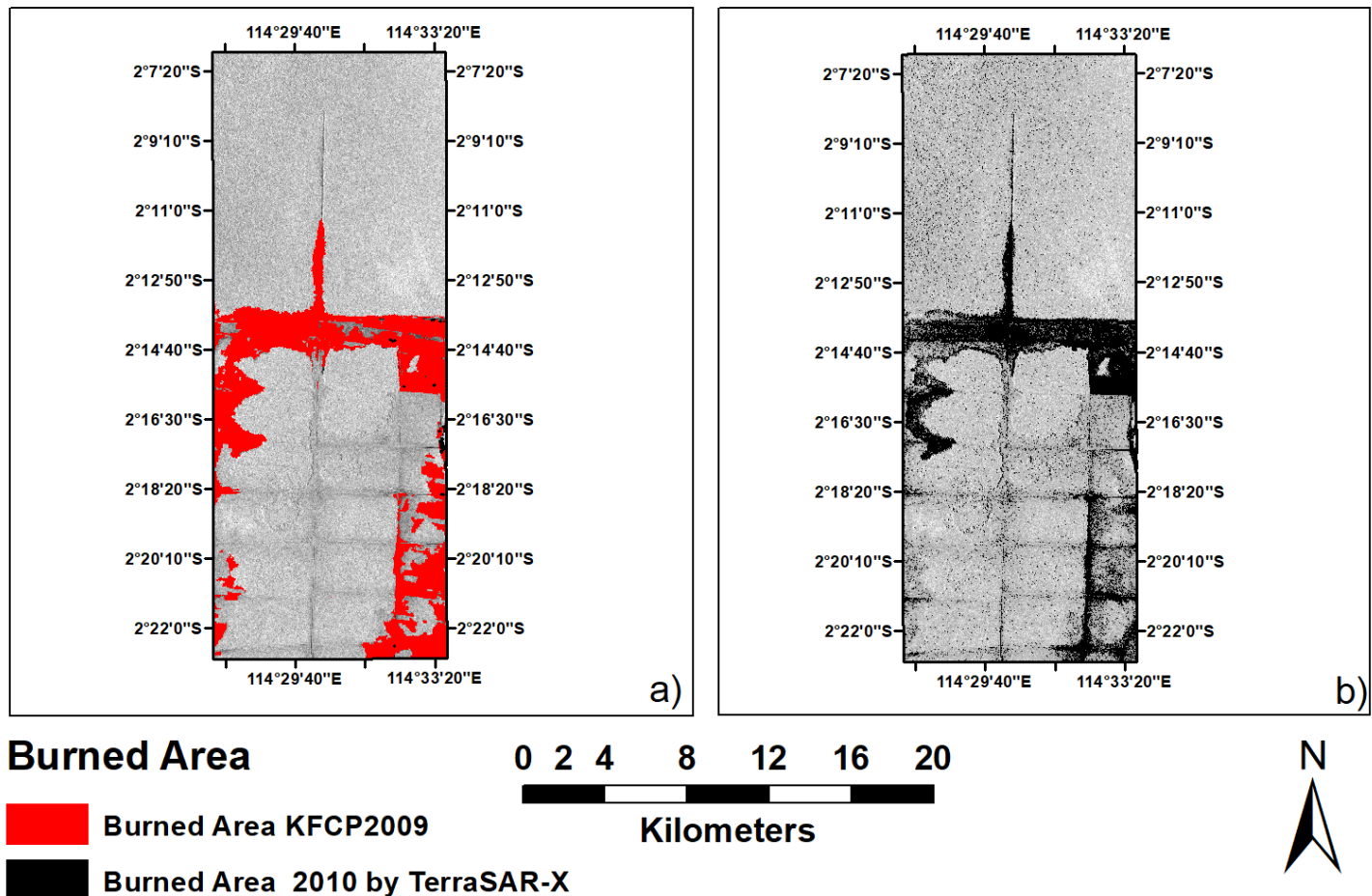

Figure 2. Burned area map in the location of the MRP site Central Kalimantan, Indonesia: (a) burned area in 2009 by KFCP (KFCP Vegetation Monitoring, 2014); (b) burned area in 2010 by TerraSAR-X satellite image $H H / H V$ polarization

Table 2. Confusion matrix illustrating the results of the estimation of the burned area based on the SAR data and using the KFCP as reference data (KFCP Vegetation Monitoring, 2014). The numbers indicate number of pixels (and percentage for omission/commission errors and overall accuracy)

\begin{tabular}{|c|c|c|c|c|c|}
\hline & \multicolumn{4}{|c|}{ Reference data } \\
\hline & & Unaffected & Burned area & Total & Commission error $(\%)$ \\
\hline \multirow{6}{*}{ 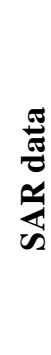 } & Unaffected & 22105909 & 2049716 & 24155625 & 8.48546 \\
\hline & Burned area & 1425878 & 4014568 & 5440446 & 26.208844 \\
\hline & Total & 23531787 & 6064284 & 29596071 & \\
\hline & Commission error $(\%)$ & 6.05937 & 33.799802 & & \\
\hline & Overall accuracy $(\%)$ & 88.26 & & & \\
\hline & Kappa & 0.63 & & & \\
\hline
\end{tabular}

The estimation of pollutant emissions from burned areas in the area of interest based on the SAR data classification results (Table 3) showed that the emission pollutants of 
$\mathrm{CO}_{2}$ was $173,019.46$ ton, $\mathrm{CO}$ (11,388.62 ton), $\mathrm{PM}_{10}$ (1,149.81 ton), $\mathrm{PM}_{2.5}$ (996.50), OC (569.43 ton) and $\mathrm{BC}$ (72.27 ton). These results indicate that $\mathrm{CO}_{2}$ has the highest annual carbon releases into the atmosphere in this study area while $\mathrm{BC}$ are estimated to the lowest value comparably (Table 3).

Table 3. Emission pollutants estimated based on the identified burned areas from the SAR satellite image classification

\begin{tabular}{c|c}
\hline Pollutant & Tropical burned forest (tons) \\
\hline $\mathrm{CO}_{2}$ & 173,019 \\
$\mathrm{CO}$ & 11,388 \\
$\mathrm{PM}_{10}$ & 1,149 \\
$\mathrm{PM}_{2.5}$ & 996 \\
$\mathrm{OC}$ & 569 \\
$\mathrm{BC}$ & 72 \\
\hline
\end{tabular}

\section{Conclusions}

In this paper the burned area of a tropical peatland area in Central Kalimantan, Indonesia was estimated based on a very high spatial resolution SAR satellite image and evaluate against field collected data reported from KFCP (KFCP Vegetation Monitoring, 2014). The two results agree spatially in regard to the distribution of burned areas. The burned area estimated from the SAR image was subsequently input in an equation developed to estimate pollution emittance. We found that the average annual carbon release from the area of study into the atmosphere is $173,019.46$ ton $\mathrm{CO}_{2}, 11,388.62$ ton $\mathrm{CO}, 1,149.81$ ton $\mathrm{PM}_{10}, 996.50$ ton $\mathrm{PM}_{2.5}, 569.43$ ton $\mathrm{OC}$ and 72.27 ton BC. The workflow presented, based on SAR satellite data, can be followed to map the burned area, estimate the cumulative land affected by fire and its corresponding biomass and quantitatively approximate the pollutants emission. The future research direction is a comparative analysis between SAR and other optical satellite images, such as Landsat and Sentinel-2, to improve the accuracy of the results.

Acknowledgements. The authors would like to express their profound appreciation and gratitude to GEO-Informatics Research Center for Natural Resource and Environment and Southern Regional Center of Geo-Informatics and Space Technology for making available facilities for the completion of this study. We would also like to thank the Faculty of Environmental Management, Prince of Songkla University for providing funding in support of this research.

\section{REFERENCES}

[1] Andreae, M. O., Merlet, P. (2001): Emission of trace gases and aerosols from biomass burning. - Global Biogeochemical Cycles 15(4): 955-966.

[2] Ballhorn, U., Siegert, F., Mason, M., Limin, S. (2009): Derivation of burn scar depths and estimation of carbon emissions with LIDAR in Indonesian peatlands. - Proceedings of the National Academy of Sciences 106(50): 21213-21218.

[3] Belenguer, P. M. A., Tanase, M. A., Fernandez, C. A., Chuvieco, E. (2018): Temporal backscattering coefficient decorrelation in burned areas. - Active and Passive Microwave Remote Sensing for Environmental Monitoring II (Vol. 10788, p. 107880T). International Society for Optics and Photonics, SPIE, Bellingham, WA. 
[4] Broich, M., Tulbure, M. G., Wijaya, A., Weisse, M., Stolle, F. (2017): Quantifying South East Asia's Forest Degradation Using Latest Generation Optical and Radar Satellite Remote Sensing. - AGU Fall Meeting Abstracts. American Geophysical Union, Washington, DC.

[5] Carlson, K. M., Curran, L. M., Asner, G. P., Pittman, A. M., Trigg, S. N., Adeney, J. M. (2013): Carbon emissions from forest conversion by Kalimantan oil palm plantations. Nature Climate Change 3(3): 283.

[6] Chaiyo, U., Garivait, S. (2014): Estimation of black carbon emissions from dry dipterocarp forest fires in Thailand. - Atmosphere 5: 1002-1019.

[7] Congalton, R. G. (1991): A review of assessing the accuracy of classifications of remotely sensed data. - Remote Sensing of Environment 37(1): 35-46.

[8] FAO (2003): State of World's Forest. - Food and Agriculture Organization of the United Nations. http:////rmportal.net/library///A/2/b/fao-2003-state-of-the-worlds-forests/fao2003-state-of-the-world-s-forests/view.

[9] Fawzi, N. I., Husna, V. N., Helms, J. A. (2018): Measuring deforestation using remote sensing and its implication for conservation in Gunung Palung National Park, West Kalimantan, Indonesia. - IOP Conference Series: Earth and Environmental Science. IOP Publishing 149(1): 012038.

[10] Grinand, C., Rakotomalala, F., Gond, V., Vaudry, R., Bernoux, M., Vieilledent, G. (2013): Estimating deforestation in tropical humid and dry forests in Madagascar from 2000 to 2010 using multi-date Landsat satellite images and the random forests classifier. - Remote Sensing of Environment 139: 68-80.

[11] Hao, W. M., Liu, M. H. (1994): Spatial and temporal distribution of tropical biomass burning. - Global Biogeochemical Cycles 8(4): 495-503.

[12] Hawbaker, T., Vanderhoof, M., French, N., Billmire, M., Beal, Y. J. G., Takacs, J., Caldwell, M. (2016): Automated mapping of burned areas in Landsat imagery; tracking spatial and temporal patterns of burned areas and greenhouse gas emissions in the Southern Rocky Mountains, USA. - EGU General Assembly Conference Abstracts 18: 10709.

[13] Hooijer, A., Page, S., Canadell, J. G., Silvius, M., Kwadijk, J., Wösten, H., Jauhiainen, J. (2010): Current and future CO2 emissions from drained peatlands in Southeast Asia. Biogeosciences 7: 1505-1514.

[14] Immirzi, C. P. (1992): The global status of peatlands and their role in carbon cycling. - A Report for Friends of the Earth: 62-84.

[15] International Panel on Climate Change (IPCC) (2006): IPCC Guidelines for National Greenhouse Gas Inventories. - IPCC, Geneva.

[16] Joshi, N., Mitchard, E. T., Woo, N., Torres, J., Moll, R. J., Ehammer, A., Fensholt, R. (2015): Mapping dynamics of deforestation and forest degradation in tropical forests using radar satellite data. - Environmental Research Letters 10(3): 034014.

[17] Junpen, A., Garivait, S., Bonnet, S. (2013): Estimating emissions from forest fires in Thailand using MODIS active fire product and country specific data. - Asia-Pacific Journal of Atmospheric Sciences 49: 389-400.

[18] Junpen, A., Pansuk, J., Kamnoet, O., Cheewaphongphan, P., Garivait, S. (2018): Emission of air pollutants from rice residue open burning in Thailand. - Atmosphere 9: 449.

[19] KFCP Vegetation Monitoring (2014): Vegetation Monitoring, Fire Management Monitoring, and Peat and Hydrology Monitoring. - Kalimantan Forests and Climate Partnership (KFCP) http://www.fordamof.org//files/Vegetation_Fire_Management_Peat_and_Hydrology_Mo nitoring_PA7.pdf (accessed on 28 January 2014).

[20] Kim, D. H., Sexton, J. O., Townshend, J. R. (2015): Accelerated deforestation in the humid tropics from the 1990s to the 2000s. - Geophysical Research Letters 42(9): 34953501 . 
[21] Koh, L. P., Butler, R. A., Bradshaw, C. J. (2009): Conversion of Indonesia's peatlands. Frontiers in Ecology and the Environment 7(5): 238-238.

[22] Krasovskii, A., Maus, V., Yowargana, P., Pietsch, S., Rautiainen, M. (2018): Monitoring deforestation in rainforests using satellite data: a pilot study from Kalimantan, Indonesia. - Forests 9(7): 389.

[23] Li, F., Bond, L. B., Levis, S. (2014): Quantifying the role of fire in the Earth system Part 2: Impact on the net carbon balance of global terrestrial ecosystems for the 20th century. - Biogeosciences 11: 1345-1360.

[24] Mitchard, E. (2015): Synthesis of the State of the Art of Above-Ground Biomass Estimation Using Remote Sensing. - Consulting Study 9. High Carbon Stock Science Study.

[25] Moore, S., Gauci, V., Evans, C. D., Page, S. E. (2011): Fluvial organic carbon losses from a Bornean blackwater river. - Biogeosciences 8(4): 901-909.

[26] Nugroho, H. Y., Van, D. V. A., Skidmore, A. K., Hussin, Y. A. (2018): Expansion of traditional land-use and deforestation: a case study of an adat forest in the Kandilo Subwatershed, East Kalimantan, Indonesia. - Journal of Forestry Research 29(2): 495513.

[27] Nuthammachot, N.; Phairuang, W.; Stratoulias, D. (2017): Removing speckle noise in Sentinel-1A radar satellite imagery using filtering techniques. - Journal of Remote Sensing and GIS Association of Thailand (RESGAT) 18: 80-92.

[28] Page, S. E., Rieley, J. O., Shotyk, O. W., Weiss, D. (1999): Interdependence of peat and vegetation in a tropical peat swamp forest. - Philosophical Transactions of the Royal Society of London, Series B, Biological Sciences 354: 1885-1897.

[29] Page, S. E., Siegert, F., Rieley, J. O., Boehm, H. D. V., Jaya, A., Limin. S. (2002): The amount of carbon released from peat and forest fires in Indonesia during 1997. - Nature 420(6911): 61-65.

[30] Page, S. E., Rieley, J. O., Banks, C. J. (2011): Global and regional importance of the tropical peatland carbon pool. - Global Change Biology 17(2): 798-818.

[31] Peace Report (2018): Executive Summary: Indonesia and Climate Change 2007. http://www.conflictrecovery.org/bin/PEACEClimateChange-ExecSum.pdf (accessed on 05 January 2018).

[32] Permadi, D. A., Oanh, N. T. K. (2013): Assessment of biomass open burning emissions in Indonesia and potential climate forcing impact. - Atmospheric Environment 78: 250-258.

[33] Phairuang, W., Hata, M., Furuuchi, M. (2017): Influence of agricultural activities, forest fires and agro-industries on air quality in Thailand. - Journal of Environmental Sciences (52): 85-97.

[34] Posa, M. R. C. (2011): Peat swamp forest avifauna of Central Kalimantan, Indonesia: Effects of habitat loss and degradation. - Biological Conservation 144(10): 2548-2556.

[35] Putra, E. I., Hayasaka, H., Takahashi, H., Usup, A. (2008): Recent peat fire activity in the mega rice project area Central Kalimantan Indonesia. - Journal of Disaster Research 3(5): $1-6$.

[36] Rieley, J. O., Wüst, R. A. J., Jauhiainen, J., Page, S. E., Wösten, J. H. M., Hooijer, A., Stahlhut, M. (2008): Tropical Peatlands: Carbon Stores, Carbon Gas Emissions and Contribution to Climate Change Processes. - In: Strack, M. (ed.) Peatlands and Climate Change. International Peat Society, Jyvaskyla, pp. 148-181.

[37] Saatchi, S. (2015): Mapping Tropical Forest Biomass: Synthesis of Ground and Remote Sensing Inventory. - Consulting Report 2. High Carbon Stock Science Study.

[38] Shrestha, R. M., Kim, O. N. T., Shrestha, R. P., Rupakheti, M., Rajbhandari, S., Permadi, D. A., Kanabkaew, T., Iyngararasan, M. (2013): Atmospheric Brown Clouds: Emission Inventory Manual. - United Nations Environment Programme, Nairobi.

[39] Strack, M. (2008): Peatlands and Climate Change. - IPS, International Peat Society, Jyvaskyla. 
[40] Streets, D. G., Canty, T., Carmichael, G. R., De, F. B., Dickerson, R. R., Duncan, B. N., Jacob, D. J. (2013): Emissions estimation from satellite retrievals: A review of current capability. - Atmospheric Environment 77: 1011-1042.

[41] Yun, S. H., Pritchard, M. E. (2018): Satellite Radar Imaging and Its Application to Natural Hazards. - In: Singh, R., Bartlett, D. (eds.) Natural Hazards. CRC Press, Boca Raton, pp. 95-114.

[42] Zeng, Z., Estes, L., Ziegler, A. D., Chen, A., Searchinger, T., Hua, F., Wood, E. F. (2018): Highland cropland expansion and forest loss in Southeast Asia in the twenty-first century. - Nature Geoscience 11(8): 556. 